\title{
CYP2C8*6 Allele
}

National Cancer Institute

\section{Source}

National Cancer Institute. CYP2C8*6 Allele. NCI Thesaurus. Code C46034.

Human CYP2C8*6 allele is located in the vicinity of $10 \mathrm{q} 23.33$ and is approximately $33 \mathrm{~kb}$ in length. This allele, a variant form of the CYP2C8 wild-type allele, encodes cytochrome P450 2C8*6 protein. The CYP2C8*6 allele exhibits a SNP (c.511G>A) in exon 4 that results in a G171S coding change. However, this alteration in protein sequence has no effect on the enzymatic activity of the cytochrome $\mathrm{P} 4502 \mathrm{C} 8 * 6$ protein. 